\title{
PRODUKTIVITAS BEBERAPA JENIS TANAMAN PAKAN DENGAN POLA TANAM DAN DOSIS BIOSLURRY BERBEDA
}

\author{
WITARIADI, N. M. DAN N. N. C. KUSUMAWATI \\ Fakultas Peternakan Universitas Udayana \\ e-mail: witarimade@unud.ac.id
}

\begin{abstract}
ABSTRAK
Percobaan untuk mengetahui produktivitas beberapa jenis tanaman pakan dengan pola tanam dan dosis bioslurry berbeda. Percobaan dilaksanakan di rumah kaca dan berlangsung selama 3 bulan. Rancangan yang digunakan adalah rancangan acak lengkap (RAL) pola split plot dengan empat ulangan. Petak utama adalah pola tanam yaitu: Panicum maximum cv. Trichoglume (P), Clitoria ternatea (C) dan Panicum maximum cv. Trichoglume+Clitoria ternatea (PC), anak petak (subplot ) adalah dosis pupuk bioslury yaitu: o ton/ha (Do); 10 ton/ha (D1); 20 ton/ha (D2); dan 30 ton/ha (D3). Variabel yang diamati meliputi: tinggi tanaman, jumlah anakan, jumlah cabang, jumlah daun, berat kering daun, berat kering batang, berat kering akar, berat kering total hijauan, nisbah berat kering daun dengan berat kering batang, nisbah berat kering total hijauan dengan berat kering akar, dan luas daun per pot. Hasil penelitian menunjukkan bahwa tidak terjadi interaksi antara pola tanam dengan dosis bioslurry berbeda dalam meningkatkan produktivitas beberapa jenis tanaman pakan. Pola tanam campuran antara rumput Panicum maximum cv Trichoglume dan leguminosa Clitoria ternatea (PC) dapat meningkatkan produksi berat kering hijauan pakan. Pemberian pupuk bioslury dosis 10-30 ton/ha mampu meningkatkan produktivitas tanaman, dimana pertumbuhan dan hasil terbaik bila dipupuk dengan dosis 30 ton/ha. Dapat disimpulkan bahwa pola tanam campuran rumput dan leguminosa mampu meningkatkan produksi berat kering hijauan pakan, dimana hasil terbaik diperoleh dengan pemupukan bioslury 30 ton/ha.
\end{abstract}

Kata kunci: produktivitas, Panicum maximum, Clitoria ternatea, bioslurry

\section{PRODUCTIVITY OF SEVERAL TYPES FORAGE WITH DIFFERENT PATTERNS OF PLANTING AND BIOSLURRY DOSAGE}

\begin{abstract}
The experiment was to determine the productivity several types of forage with different patterns of planting and bioslurry dosage. The experiment was conducted in a greenhouse for 3 months. Completely randomized design (CRD) was used with split plot pattern, of four replications. The main plot was planting pattern of Panicum maximum cv. Trichoglume (P); Clitoria ternatea (C); and Panicum maximum cv. Trichoglume+Clitoria ternatea (PC); subplot was dosage of bioslurry fertilizer, of o tons/ha (Do); 10 tons/ha (D1); 20 tons/ha (D2); and 30 tons/ ha (D3). Variables observed were: plant height, number of tillers, number of branches, number of leaves, leaf dry weight, stem dry weight, root dry weight, total forage dry weight, leaf dry weight ratio with stem dry weight, total forage dry weight ratio with root dry weight, and leaf area per pot. The results showed that planting patterns could increase the growth of Panicum maximum cv. Trichoglume. Fertilization with bioslury dosage of 10-30 tons/ha could increase the growth of the grass and the best result was if fertilized with a dosage of 20 tons/ha (D2). It can be concluded that the growth of Panicum maximum cv Trichoglume can be increased through cropping patterns with a combination of planting between grass and legume and through fertilization with bioslurry starting from 10-30 tons/ha, and the best dosage was 20 tons/ha.
\end{abstract}

Key words: productivity, Panicum maximum, Clitoria ternatea, bioslurry 


\section{PENDAHULUAN}

Produktivitas ternak dapat ditingkatkan dengan memberikan pakan secara optimal, karena itu kualitas dan kuantitas pakan harus diperhatikan agar ternak tumbuh secara maksimal. Sumber pakan utama bagi ternak ruminansia berasal dari hijauan, yaitu dapat berasal dari rumput, daun-daunan, dan sisa-sisa panen berupa jerami. Hampir $70 \%$ dari jumlah pakan yang diberikan pada ternak ruminansia terdiri dari hijauan (Tata, 1995). Tingginya kebutuhan pakan sumber hijauan, maka perlu perhatikan dalam penyediaan, baik dari segi kuantitas maupun kualitas, sehingga sangat penting dikembangkan jenis-jenis hijauan pakan unggul yang pertumbuhannya tidak dipengaruhi oleh musim dan dapat tumbuh pada semua jenis tanah. Jenis hijauan pakan yang berpotensi dikembangkan yaitu jenis rumput Panicum maximum cv. Trichoglume dan jenis leguminosa Clitoria ternatea.

Rumput Panicum maximum cv Trichoglume merupakan tanaman pakan, yang memiliki kualitas baik untuk memenuhi kebutuhan ternak ruminansia. Rumput tersebut termasuk tanaman pakan berumur panjang, dapat beradaptasi dengan semua jenis tanah, tahan terhadap naungan, palatabel (disukai ternak). Kandungan protein rumput tersebut sebesar 17,99\% (Witariadi dan Kusumawati, 2018). Tanaman leguminosa Clitoria ternatea juga memiliki kelebihan yaitu tahan terhadap kondisi kering, dapat ditanam pada naungan dan memiliki fungsi sebagai tanaman penutup tanah, tanaman sela, dan pencegah erosi. Kandungan protein Clitoria ternate (22,07\%); kadar air $(8,38 \%)$ dan kadar abu $(8,97 \%)$ dilaporkan oleh Witariadi dan Kusumawati (2017). Kesulitan dalam menyediaan hijauan, disebabkan oleh keterbatasan lahan dan semakin menurunnya kesuburan tanah. Kondisi lahan yang digunakan untuk menanam hijauan pakan pada tanah kurang subur dan topografi lahan berlereng. Kondisi lahan seperti ini perlu ditingkatkan kesuburannya yaitu kesuburan fisik, kimia, maupun biologi tanah melalui pemupukan.

Pemupukan dengan menambahkan hara ke dalam tanah bertujuan untuk meningkatkan kesuburan dari tanah tersebut. Rustandi (1982) melaporkan bahwa melalui pemupukan maka kesuburan lahan dapat dipertahankan atau bahkan dapat ditingkatkan, sehingga dapat meningkatkan produktivitas dari tanaman yang dibudidayakan. Jenis pupuk yang dapat digunakan adalah pupuk organik (bioslurry), diamana bioslurry itu merupakan produk akhir dari pengolahan limbah biogas yang berbahan kotoran sapi. Penerapan teknologi fermentasi terhadap bioslurry bertujuan untuk mempercepat proses perombakan bahan organik, sehingga unsur hara cepat tersedia ditanah.
Bioslurry yang sudah difermentasi mengandung mikroorganisme. Bioslurry sangat baik untuk memperbaiki struktur tanah, sebagai sumber nutrisi untuk tanaman, meningkatkan kemampuan tanah mengikat atau menahan air lebih lama, meningkatkan aktivitas cacing dan mikroorganisme tanah. Kandungan bioslurry berdasarkan analisa di Laboratorium Ilmu Tanah, Fakultas Pertanian, Universitas Udayana yaitu: pH (6,72); C Organik (22,48\%); N total (1,37\%); dan P tersedia (732,45 ppm).

Keberadaan mikroorganisme di dalam tanah disamping melalui pemupukan juga dengan pengaturan pola tanam. Penanaman campuran rumput dan leguminosa pada lahan tertentu dapat membantu menyediakan hara di tanah, karena tanaman leguminosa secara aktif memfiksasi nitrogen bebas di atmosfir yang dilakukan oleh bakteri Rhizobium. Terbentuknya nodul pada tanaman leguminosa menunjukkan keberadaan bakteri Rhizobium di dalam tanah dan secara tidak langsung tanah mendapatkan hara nitrogen dari asosiasi penanaman campuran tersebut.

Arnawa et al. (2014) bahwa penggunaan limbah biogas (slurry) dosis 10-30 ton/ha memberikan pengaruh yang sama terhadap pertumbuhan dan produksi rumput Panicum maximum cv. Trichoglume. Witariadi dan Kusumawati (2018) meaporkan bahwa terjadi interaksi antara jenis dan dosis bioslurry berbeda, dimana dosis 30 ton bioslurry babi/ha, memberikan hasil yang paling baik terhadap pertumbuhan dan produksi rumput Panicum maximum cv. Trichoglume. Pemberian bioslurry 30 ton/ha pada leguminosa Clitoria ternatea memberikan respon pertumbuhan dan produksi tertinggi dengan kandungan protein: 22,07\% (Witariadi dan Kusumawati, 2017). Penanaman campuran dapat meningkatkan produktivitas lahan persatuan luas (Mansyur et al., 2005)

Berdasarkan uraian diatas, penelitian terkait belum banyak informasinya, sehingga perlu dilakukan penelitian tentang pola tanam beberapa jenis tanaman pakan dengan dosis bioslurry berbeda.

\section{MATERI DAN METODE}

\section{Tempat dan waktu penelitian}

Percobaan dilaksanakan di rumah kaca di Desa Sading, Badung dan berlangsung selama tiga bulan.

\section{Tanah dan pupuk}

Tanah yang digunakan diambil dari lahan sekitar rumah kaca di Desa Sading, Badung. Pupuk yang digunakan adalah bioslurry, diperoleh dari kelompok simantri di Desa Kelating, Tabanan. Tanah dan bioslurry dianalisis pada Laboratorium Ilmu Tanah, Fakultas Pertanian, Universitas Udayana (Tabel 1.) 


\section{Rancangan percobaan}

Penelitian ini menggunakan rancangan acak lengkap (RAL) pola split plot. Petak utama (main plot) adalah pola tanam yaitu P: Panicum maximum cv. Trichoglume, $C$ : Clitoria ternatea, dan PC : Panicum maximum cv. Trichoglume+Clitoria ternatea, sedangkan anak petak (subplot) yaitu dosis pupuk terdiri atas: o ton/ha (Do); 10 ton/ha (D1); 20 ton/ha (D2); dan 30 ton/ha (D3). Dari faktor tersebut diperoleh 12 kombinasi perlakuan dan setiap kombinasi perlakuan di ulang 4 kali, sehingga terdapat 48 pot percobaan.

\section{Variabel yang diamati}

Variabel yang diamati pada penelitian ini meliputi: varibel pertumbuhan (tinggi tanaman, jumlah anakan, jumlah daun), variabel produksi (berat kering daun, berat kering batang, berat kering akar, berat kering total hijauan), dan variabel karakteristik tumbuh (nisbah berat kering daun dengan berat kering batang, nisbah berat kering total hijauan dengan berat kering akar, luas daun per pot).

\begin{tabular}{|c|c|c|c|}
\hline No. & Uraian & Tanah & Bioslurry \\
\hline 1 & $\mathrm{pH}(1: 2,5) \mathrm{H}_{2} \mathrm{O}$ & $6,9(N)$ & $7,720(A A)$ \\
\hline 2 & DHL (mmhos/cm) & $2,00(R)$ & $2,74(S)$ \\
\hline 3 & C Organik (\%) & 2,15 (S) & 9,25 (ST) \\
\hline 4 & N Total (\%) & $0,120(R)$ & $0,83(\mathrm{ST})$ \\
\hline 5 & P Tersedia (ppm) & $183,60(\mathrm{ST})$ & 333,77 (ST) \\
\hline 6 & K Tersedia (ppm) & $158,31(\mathrm{~S})$ & 767,52 (ST) \\
\hline \multicolumn{4}{|c|}{7 Kadar Air : } \\
\hline & KU (\%) & 10,22 & 18,69 \\
\hline & $\mathrm{KL}(\%)$ & 32,02 & \\
\hline & Pasir (\%) & 59,88 & \\
\hline & Debu (\%) & 22,60 & \\
\hline & Liat (\%) & 17,52 & \\
\hline
\end{tabular}

$\begin{array}{lll}\text { Keterangan : } & & \\ \text { Singkatan: } & \text { Metode: } & \text { Keterangan: } \\ \text { DHL: Daya Hantar Listrik } & \text { C Organik : Metode Walkley \& Black } & \text { R,S : Rendah, Sedang } \\ \text { KU : Kering Udara } & \text { N Total : Metode Kjelhall } & \text { AA : Agak Alkalis } \\ \text { KL : Kapasitas Lapang } & \text { KU dan KL : Metode Graviment } & \text { ST : Sangat Tinggi } \\ \text { P,K : Posfor,Kalium } & \text { P : : Metode bray-1 } & \text { N : Netral } \\ \text { C,N : Karbon, Nitrogen } & \text { Tekstur : Metode Pipet } & \end{array}$

\section{Analisis statistik}

Data yang diperoleh dianalisis dengan sidik ragam. Apabila diantara nilai rata-rata perlakuan menunjukkan perbedaan nyata $(\mathrm{P}<0,05)$, maka analisis dilanjutkan dengan uji jarak berganda Duncan (Steel and Toree, 1991).

\section{HASIL DAN PEMBAHASAN}

Hasil penelitian menunjukkan bahwa tidak terjadi interaksi antara pola tanam dan dosis bioslurry berbeda terhadap produktivitas beberapa jenis tanaman pakan.
Hal ini mengindikasikan bahwa antara pola tanam dan dosis bioslurry secara bersama-sama atau sendirisendiri dalam mempengaruhi pertumbuhan dan produksi beberapa jenis tanaman pakan. Pengaruh dosis bioslurry berbeda memberikan hasil yang sama pada variabel tinggi tanaman dan jumlah anakan, dimana tinggi tanaman pada perlakuan 20 ton/ha (D2) lebih tinggi. Hasil analisa bioslurry (Tabel 1) kandungan unsur hara nitrogen sangat tinggi sehingga bioslurry yang diberikan ke tanaman dapat dimanfaatkan secara maksimal untuk melakukan pertumbuhan keatas (tinggi tanaman) dan melakukan pertumbuhan kesamping (vegetatif) untuk perbanyakan anakan. Harjadi (1983) menyatakan bahwa ada dua fase yang berbeda dalam pertumbuhan dan perkembangan tanaman yaitu fase vegetatif dan fase reproduktif. Pada fase vegetatif terutama akan terjadi perkembangan akar, daun dan batang. Terpenuhinya unsur hara pada perlakuan D2, menyebabkan tanaman tumbuh dengan baik, dan terlihat juga pada variabel jumlah daun dan jumlah cabang lebih tinggi dibandingkan perlakuan lainnya. Kandungan nitrogen yang tinggi pada bioslurry merupakan unsur hara utama untuk pertumbuhan tanaman yaitu digunakan untuk pembentukan dan pertumbuhan bagian-bagian vegetatif tanaman seperti: daun, batang dan akar ( Sutedjo,2002).

Respon pertumbuhan beberapa jenis tanaman yang diberi bioslury sangat baik, sehingga berat kering daun dan berat kering batang yang dihasilkan juga tinggi (Tabel 3). Penambahan bioslurry ke dalam tanah ternyata mengakibatkan peningkatan kadar C-organik tanah (Tabel 1). Kandungan C-organik yang tinggi dimanfaatkan oleh tanaman untuk pertumbuhan dan meningkatkan hasil tanaman. Umar (2002) menyatakan bahwa perbedaan kandungan $\mathrm{C}$-organik tanah adalah sebagai akibat dari perbedaan takaran bahan organik yang diberikan. Bioslurry memiliki manfaat yaitu: memperbaiki struktur fisik tanah sehingga tanah menjadilebih gembur, meningkatkan kemampuan tanah mengikat atau menahan air lebih lama yang bermanfaat saat musim kemarau, meningkatkan kesuburan tanah sehingga tanah menjadi lebih bernutrisi dan lengkap kandungannya dan meningkatkan aktivitas cacing dan mikroorganisme tanah yang bermanfaat untuk tanah dan tanaman. Gardner et al. (1991) menyebutkan bahwa pertumbuhan merupakan akibat adanya interaksi antara berbagai faktor internal perangsang pertumbuhan (genetik) dan faktor external yang meliputi iklim, tanah, dan kondisi biologis dari lingkungan.

Luas daun tanaman yang dipupuk dengan bioslurry lebih lebar, ini karena kandungan C-organik dan kadar air yang terkandung pada bioslurry lebih tinggi (Tabel 1). Purwowidodo (1983) menyatakan bahwa tanah sebagai media pertumbuhan tanaman memberikan 
Tabel 2. Pertumbuhan beberapa jenis tanaman pakan dengan pola tanam dan dosis bioslurry berbeda

\begin{tabular}{|c|c|c|c|c|c|c|c|}
\hline \multirow{2}{*}{ Variabel } & \multirow{2}{*}{$\begin{array}{c}\text { Pola } \\
\text { Tanam²) }\end{array}$} & \multicolumn{4}{|c|}{ Dosis Bioslurry ${ }^{1)}$} & \multirow{2}{*}{ Rataan } & \multirow{2}{*}{$\mathrm{SEM}^{4}$} \\
\hline & & DO & D1 & D2 & D3 & & \\
\hline \multirow[t]{4}{*}{ Tinggi Tanaman } & $\mathrm{P}$ & 91,25 & 85,50 & 89,25 & 67,75 & $83,44^{\times 3)}$ & 6,19 \\
\hline & C & 91,25 & 82,50 & 113,75 & 74,75 & $90,56^{x}$ & \\
\hline & PC & 81,00 & 95,75 & 72,50 & 79,81 & $79,81^{x}$ & 7,15 \\
\hline & Rataan & $87,83^{A}$ & $87,91^{A}$ & $91,83^{A}$ & $70,83^{A}$ & & \\
\hline \multirow[t]{4}{*}{ Jumlah Daun } & $P$ & 25,25 & 59,00 & 29,00 & 26,75 & $35,00^{X}$ & 1,96 \\
\hline & C & 27,50 & 15,50 & 46,25 & 29,25 & $29,63^{Y}$ & \\
\hline & PC & 19,50 & 20,50 & 45,25 & 28,00 & $28,31^{Y}$ & 2,27 \\
\hline & Rataan & $24,10^{C 3)}$ & $31,67^{\mathrm{B}}$ & $40,17^{A}$ & $28,00^{B C}$ & & \\
\hline \multirow[t]{4}{*}{ Jumlah Anakan } & $P$ & 2,00 & 4,75 & 3,00 & 1,50 & $2,81^{X}$ & 0,49 \\
\hline & C & 2,00 & 3,75 & 4,25 & 3,00 & $3,25^{X}$ & \\
\hline & PC & 3,50 & 2,50 & 1,00 & 1,75 & $2,81^{x}$ & 0,56 \\
\hline & Rataan & $2,50^{A}$ & $3,67^{\mathrm{A}}$ & $2,75^{\mathrm{A}}$ & $2,08^{A}$ & & \\
\hline
\end{tabular}

Keterangan:

1) D0: 0 ton/ha, D1:10 ton /ha, D2: 20 ton/ha, D3: 30 ton /ha.

2) P (Panicum maximum cv.Trichoglume ); C (Clitoria ternatea) dan PC (Panicum maximum cv. Trichoglume+Clitoria ternatea)

3) Nilai dengan huruf kapital berbeda pada kolom atau baris yang sama berbeda nyata $(P<0,05)$

4) SEM : Standard Error of the Treatment Means

Tabel 3. Produksi beberapa jenis tanaman pakan dengan pola tanam dan dosis bioslurry berbeda

\begin{tabular}{|c|c|c|c|c|c|c|c|}
\hline \multirow{2}{*}{ Variabel } & \multirow{2}{*}{$\begin{array}{c}\text { Pola } \\
\text { Tanam }^{2)}\end{array}$} & \multicolumn{4}{|c|}{ Dosis Bioslurry ${ }^{1)}$} & \multirow{2}{*}{ Rataan } & \multirow{2}{*}{ SEM $^{4}$} \\
\hline & & DO & D1 & D2 & D3 & & \\
\hline \multirow[t]{4}{*}{ Berat kering Daun } & $P$ & 0,75 & 6,50 & 3,25 & 3,37 & $3,46^{X}$ & 0,26 \\
\hline & c & 0,78 & 0,58 & 5,15 & 6,12 & $3,15^{x}$ & \\
\hline & PC & 2,93 & 0,57 & 5,00 & 5,31 & $3,46^{\mathrm{X}}$ & 0,33 \\
\hline & Rataan & $1,48^{C}$ & $2,56^{\mathrm{B}}$ & $4,46^{\mathrm{A}}$ & $4,94^{\mathrm{A}}$ & & \\
\hline \multirow[t]{4}{*}{ Berat Kering Batang } & $P$ & 0,58 & 10,37 & 6,47 & 7,38 & $6,20^{X}$ & 0,58 \\
\hline & c & 0,55 & 0,40 & 8,38 & 9,25 & $4,64^{x}$ & \\
\hline & PC & 6,88 & 0,30 & 8,63 & 8,00 & $5,95^{x}$ & 0,67 \\
\hline & Rataan & $2,67^{\mathrm{B}}$ & $3,69^{\mathrm{B}}$ & $7,83^{A}$ & $8,20^{\mathrm{A}}$ & & \\
\hline \multirow[t]{4}{*}{ Berat Kering Akar } & $P$ & 0,57 & 3,87 & 2,37 & 3,75 & $2,64^{X}$ & 0,29 \\
\hline & C & 0,75 & 0,27 & 2,50 & 5,62 & $2,28^{X}$ & \\
\hline & PC & 2,62 & 0,22 & 4,00 & 3,75 & $2,65^{x}$ & 0,33 \\
\hline & Rataan & $1,31^{\mathrm{C}}$ & $1,45^{\mathrm{C}}$ & $2,95^{\mathrm{B}}$ & $4,37^{\mathrm{A}}$ & & \\
\hline \multirow[t]{4}{*}{ Berat Kering Total Hijauan } & $P$ & 1,33 & 16,87 & 9,73 & 10,75 & $9,66^{\mathrm{Y} 3)}$ & 0,95 \\
\hline & c & 1,33 & 0,97 & 13,50 & 15,38 & $7,79^{Y}$ & \\
\hline & PC & 9,81 & 0,88 & 13,63 & 13,33 & $11,19^{\mathrm{X}}$ & 1,10 \\
\hline & Rataan & $4,15^{\mathrm{B} 3)}$ & $6,24^{B}$ & $12,28^{A}$ & $13,15^{\mathrm{A}}$ & & \\
\hline
\end{tabular}

Keterangan:

1) DO: 0 ton/ha, D1:10 ton/ha, D2: 20 ton/ha, D3: 30 ton /ha.

2) P (Panicum maximum cv.Trichoglume); C (Clitoria ternatea) dan PC (Panicum maximum cv. Trichoglume+Clitoria ternatea)

3) Nilai dengan huruf kapital berbeda pada kolom atau baris yang sama berbeda nyata $(P<0,05)$

4) SEM : Standard Error of the Treatment Means

pengaruh bagi kelangsungan hidup tanaman, dimana kelembaban tanah memegang peranan yang sangat penting dalam proses metabolisme mikroba dan secara tidak langsung berpengaruh terhadap suplay oksigen. Kadar uap air yang tinggi pada tanah yang disebabkan penambahan bioslurry mengakibatkan kondisi tanah menjadi lembab, sehingga populasi mikroorganisme dalam tanah berkembang baik dan mampu menguraikan bahan organik dengan cepat. Hasil penguraian bahan organik oleh mikroorganisme menyebabkan unsur hara tersedia lebih awal, dimana unsur hara ini akan digunakan oleh tanaman untuk pertumbuhan. Luas daun yang lebar, memungkinkan tanaman untuk meningkatkan proses fotosintesis. Kapasitas fotosintesis akan berlangsung lebih tinggi sehingga hasil fotosintesis berupa karbohidrat dan protein memberikan hasil yang maksimal. Karbohidrat dan protein merupakan komponen penyusun berat kering tanaman. Hasil fotosintesis ini akan disebarkan keseluruh bagian tanaman, sehingga pertumbuhan dan berat kering tanaman yang dihasilkan meningkat (Tabel 2 dan 3).

Hasil nisbah berat kering daun dengan berat kering batang menunjukkan kualitas hijauan pakan. 
Tabel 4. Karakteristik tumbuh beberapa jenis tanaman pakan dengan pola tanam dan dosis bioslurry berbeda

\begin{tabular}{|c|c|c|c|c|c|c|c|}
\hline \multirow{2}{*}{ Variabel } & \multirow{2}{*}{$\begin{array}{c}\text { Pola } \\
\text { Tanam } 2)\end{array}$} & \multicolumn{4}{|c|}{ Dosis Bioslurry ${ }^{1)}$} & \multirow{2}{*}{ Rataan } & \multirow{2}{*}{ SEM $^{4)}$} \\
\hline & & DO & D1 & D2 & D3 & & \\
\hline \multirow[t]{4}{*}{ Luas Daun Per Pot } & $\mathrm{P}$ & 2,450 & 5,711 & 2,473 & 6,817 & $4.363^{X}$ & 441,612 \\
\hline & C & 3,391 & 1,638 & 4,504 & 10,325 & $4.965^{X}$ & \\
\hline & $\mathrm{PC}$ & 3,874 & 2,218 & 5,343 & 8,998 & $5,108^{X}$ & 509,93 \\
\hline & Rataan & $3,239^{\mathrm{B} 3)}$ & $3,189^{\mathrm{B}}$ & $4,107^{\mathrm{B}}$ & $8,714^{\mathrm{A}}$ & & \\
\hline \multirow[t]{4}{*}{ Nisbah Daun/Batang } & $\mathrm{P}$ & 1,25 & 0,62 & 0,51 & 0,53 & $0,88^{X}$ & 1,57 \\
\hline & $\mathrm{C}$ & 1,41 & 0,65 & 0,62 & 0,73 & $1,15^{\mathrm{X}}$ & \\
\hline & PC & 0,46 & 0,80 & 0,56 & 0,67 & $0,92^{x}$ & 1,18 \\
\hline & Rataan & $0,55^{A}$ & $0,69^{A}$ & $0,56^{A}$ & $0,65^{A}$ & & \\
\hline \multirow[t]{4}{*}{ Nisbah Akar/Total Hijauan } & $P$ & 0,57 & 0,23 & 0,25 & 0,35 & $0,35^{x}$ & 0,17 \\
\hline & $\mathrm{C}$ & 1,43 & 0,27 & 0,19 & 0,56 & $0,56^{x}$ & \\
\hline & $\mathrm{PC}$ & 0,15 & 0,20 & 0,30 & 0,28 & $0,25^{x}$ & 0,20 \\
\hline & Rataan & $0,72^{A}$ & $0,25^{A}$ & $0,24^{A}$ & $0,33^{A}$ & & \\
\hline
\end{tabular}

Keterangan:

1) D0: 0 ton/ha, D1:10 ton /ha, D2: 20 ton/ha, D3: 30 ton /ha.

2) P (Panicum maximum cv.Trichoglume ); C (Clitoria ternatea) dan PC (Panicum maximum cv. Trichoglume+Clitoria ternatea)

3) Nilai dengan huruf kapital berbeda pada kolom atau baris yang sama berbeda nyata $(P<0,05)$

4) SEM : Standard Error of the Treatment Means

Semakin tinggi nilai nisbah yang didapat menunjukan kualitas hijauan lebih baik karena berat kering daun yang dihasilkan lebih tinggi dibandingkan berat kering batang. Pemberian bioslurry berbeda memberikan hasil yang sama pada semua variabel, ini menandakan bahwa dosis bioslurry tidak mempengaruhi kualitas hijauan pakan yang dihasilkan. Top root ratio perlakuan yang diberikan dosis bioslurry berbeda, juga memberikan hasil yang sama pada semua variabel perlakuan, dimana tinggi rendahnya hasil top root ratio dipengaruhi oleh nilai berat kering total hijauan dan berat kering akar.

Pengaruh pola tanam campuran antara rumput Panicum maximum cv. Trichoglume dengan leguminosa Clitoria ternatea dimungkinkan akan terjadi persaingan atau saling berebut unsur hara. Hal ini akan mempengaruhi komponen pertanaman yang berlangsung selama periode pertumbuhan tanaman, juga mampu mempengaruhi hasil kedua tanaman tersebut. Mansyur et al. (2005) menyatakan bahwa keuntungan dari pola pertanaman campuran antara rumput dan leguminosa dapat meningkatkan produksi hijauan, dibandingkan dengan pertanaman monokultur. Berat kering total hijauan pada pertanaman campuran paling tinggi dibandingkan perlakuan lainya. Gardener et al. (1991) menyatakan bahwa pertanaman campuran leguminosa memberikan sumbangan nitrogen pada rumput selama pertumbuhan. Percampuran leguminosa dan rumput mempunyai potensi untuk menghasilkan kualitas hijauan yang lebih baik, disamping itu pertanaman campuran dapat menekan gulma dan meningkatkan kesuburan tanah ( Horne dan Stur, 1999).

\section{SIMPULAN}

Berdasarkan hasil penelitian dapat disimpulkan bahwa tidak terjadi interaksi antara pola tanam dengan dosis bioslurry berbeda dalam meningkatkan produktivitas beberapa jenis tanaman pakan. Pola tanam campuran rumput Panicum maximum cv. Trichoglume dan leguminosa Clitoria ternatea dapat meningkatkan produksi berat kering hijauan, sedangkan pemberian bioslurry dosis 10-30 ton/ha mampu meningkatkan produktivitas tanaman, dimana dosis bioslurry 30 ton/ ha memberikan pertumbuhan dan hasil terbaik.

\section{UCAPAN TERIMAKASIH}

Pada kesempatan ini penulis mengucapkan banyak terimakasih kepada Rektor dan Ketua LPPM atas dana yang diberikan melalui DIPA PNBP Universitas Udayana, sehingga penelitian dan penulisan artikel ilmiah dapat terlaksana.

\section{DAFTAR PUSTAKA}

Arnawa, I.W, Budiasa I.K.M., Witariadi N.M. 2014. Pertumbuhan dan produksi rumput benggala (Panicum maximum cv.Trchoglume) yang diberi pupuk organik dengan dosis berbeda. E-Jurnal Peternakan Tropika.Vol.II No.2.

https://ojs.unud.ac.id/index.php/tropika/article/ view/18463/11970

Gardener,F.P, R.B.Pearce, R.L. Mitchell. 1991. Fisiologi Tanaman Budidaya. Penerbit Universitas Indonesia (UI-Press). Jakarta. 
Harjadi, S. 1983. Pengantar Agronomi. PT. Gramedia, Jakarta.

Horne.P.M.,W.W.Stur,1999. Developing Forage Technologies With Smallholder Farmer. Monograph. No.62.80.pp.

Mansyur,N.P.,Indrani.,S.Lawat. 2005. Peranan Leguminosa Tanaman Penutup Pada Sistem Pertanaman Campuran Jagung Untuk Hijauan Pakan.

Purwowidodo.1983. Tehnologi Mulsa. Jakarta. Dewaruci Press.

Rustandi. 1982. Pengaruh Tingkat Pemupukan Kalium dan Tinggi Pemotongan terhadap Produksi dan Mutu Hijauan Rumput Gajah. Skripsi, LPP.Unsrat Menado.

Steel,R.G.D. and J.H.Torrie.1991. Principles and Procedure of Statistic. McGraw Hill Book Co. Inc. New York.

Sutedjo,M.M.2002. Pupuk dan Cara Pemupukan. Penerbit Rineka Cipta, Jakarta.

Tata, T. 1995. Pengaruh Jenis dan Dosis Kotoran Ternak Terhadap Produktifitas Arachis pintoi. Skripsi. Fakultas Peternakan Universitas Udayana. Denpasar.
Umar. 2002. Pengaruh Takaran Pupuk Tembaga dan Bahan Organik Terhadap Pertumbuhan dan Hasil Kedelai di Tropudult. Tesis. PS. Agronomi Ilmu-ilmu Pertanian. Universitas Gadjah Mada. Yogyakarta

Witariadi,N.M., dan N.N.C. Kusumawati. 2017. Pertumbuhan dan produksi leguminosa pada pemotongan kedua yang dipupuk dengan bio slurry. Jurnal Pastura Vol.8, No. 1 https://ojs.unud.ac.id/ index.php/pastura/article/view/45533/27641

Witariadi,N.M., dan N.N.C. Kusumawati. 2017. Produktivitas panaman leguminosa (Centrocema pubescens dan Clitoria ternatea) yang dipupuk dengan pupuk bio slurry. Majalah Ilmiah Peternakan Vol. 20, No.3.

https://ojs.unud.ac.id/index.php/mip/article/ view/41387/25185

Witariadi,N.M., dan N.N.C. Kusumawati. 2018. Produktivitas rumput Panicum maximum yang dipupuk dengan jenis dan dosis bio slurry berbeda. Jurnal Pastura,Vol. 7, No. 2.

https://ojs.unud.ac.id/index.php/pastura/article/ view/45513/27622 